\title{
Transformative Learning in the Discipline of Nursing
}

\author{
Ruta Renigere ${ }^{*}$ \\ Institute of Education and Home Economics, Latvia University of Agriculture Latvia \\ *Corresponding author: rutarenigere@inbox.lv
}

Received October 08, 2014; Revised December 08, 2014; Accepted December 14, 2014

\begin{abstract}
Transformative education in nursing is a manifestation of the complementarity of nursing and the ecology of education with an aim to base learning and learning outcomes - knowledge, skills and competences in the ecological paradigm. The author of the research has approbated the principles of the ecology of education in the curricula and study courses of several medical colleges, as well as in the curricula of informal education. A student survey was performed to clarify how participants of different nursing study programs understand the concept of ecology and transformative education, and its connection with education and health care.
\end{abstract}

Keywords: transformative learning, education for sustainable development, ecological paradigm

Cite This Article: Ruta Renigere, “Transformative Learning in the Discipline of Nursing." American Journal of Educational Research, vol. 2, no. 12 (2014): 1207-1210. doi: 10.12691/education-2-12-12.

\section{Introduction}

In 2002, the United Nations General Assembly passed a resolution "UN Decade of Education for Sustainable Development” for the period between 2005 and 2014. The vision of the decade is a world where everyone can benefit from quality education and learn about the values, actions and lifestyle that ensure a sustainable future and a positive transformation of society with an aim to provide the incorporation of the principles of education for sustainable development in the curricula of schools and other educational institutions, to emphasize the importance of education on the way towards sustainable development and the fact that the quality and content of education in all aspects of education and learning is an important prerequisite for sustainable development of education $[1,2]$.

"The UNESCO Decade of Education for Sustainable Development” mentions five types or pillars of learning:

Learning to know

Learning to do

Learning to live together, learning to live with others

Learning to be

Learning to transform oneself and society.

In the context of lifelong learning, each of the five types of education for sustainable development is important for nursing education. The importance of the pillar of education 'learning to transform oneself and society' is characterized by the fact that this pillar was included in the UNESCO strategy in the 21st century in addition to the four other pillars of education that were defined at the end of the 20th century.

The pillar of education 'learning to transform oneself and society' corresponds to transformative education. All other pillars are also important in the realisation of transformative education. The aim of the research is to characterize transformative education and the necessity of its implementation in specific nursing education programs from students' point of view.

\section{Transformative Education and Ecology of Education}

Transformative education and transformative learning, complementary supplemented with the ecology of education, is a way to develop nursing studies in line with the global tendency of the 21st century - education for sustainable development. Transformative education is characteristic of the ecological paradigm of education that is a framework for the development of the ecology of education. The ecology of education is an interdisciplinary approach that integrates natural, social and humanitarian sciences, studies the interrelation of a person and the multi - dimensional environment from a holistic perspective within the aspect of education as a process and a result of human activities [2]. The author's experience and evaluation of the concepts found in many publications have allowed formulating a hypothetical assumption that the ecological paradigm in nursing education and practice develops the ecological competence and facilitates education for sustainable development.

The ecological paradigm of nursing education should be perceived as:

- integrative thinking - intuitive, synthesizing, holistic and non-linear;

- integrative preservation/ conservation, cooperation, the values of quality and partnership;

- social organizations as networks

- ethics as an ecocentric value, as a result of which researchers, scholars and educators bear not only intellectual, but also moral responsibility for the outcomes of their research. 
Nursing education is rooted in the mechanical paradigm that is grounded in transmissive education; it impedes transition to the ecological paradigm and also an understanding of the lifelong transformative learning process. Transformative education and transformative learning is a way to facilitate transition of nursing education from the mechanical paradigm in health care to the ecological paradigm.

Transformative learning includes deep structural changes in the basic aspects of thinking, feeling and behaviour. It is a shift of consciousness that deeply and irreversibly changes our existence in the world. Such a shift is related to our understanding of ourselves and our place in the world, our relationship with other people and natural world, our perception of power relations in the interconnected class, race and gender structures, our senses, visions of an alternative lifestyle and ideas about the feasibility of achieving social justice, peace and personal joy $[3,4]$.

Transformative learning in nursing education increases sensibility and ethical responsibility of a nurse-student.

Learning is most intensive in the situations characterised by balance between safety and challenge, certainty and agitation, stability and instability. In such circumstances, creativity and innovation spring up and transformative learning takes place [5].

The theory of transformative learning was introduced by Professor Jack Mezirow from the Columbia University and many other scholars have substantially enriched the concept and the theory [6-13]. Based on the realizations of W. Van de Bohr and other authors on the integration of sustainable education in adult education, S. Sterling characterizes the progress from transmissive education to transformative education as shown in Table 1.

Table 1. From transmissive to transformative education

\begin{tabular}{|c|c|}
\hline From & To \\
\hline Transmissive learning & Learning through discovery \\
\hline Teacher-centred approach & Learner-centred approach \\
\hline Individual learning & Collaborative learning \\
\hline $\begin{array}{c}\text { Learning dominated by theory } \\
\text { and content orientation }\end{array}$ & $\begin{array}{c}\text { Practice-oriented learning linking } \\
\text { theory and experience }\end{array}$ \\
\hline $\begin{array}{c}\text { Emphasis only on cognition } \\
\text { and real issues orientation }\end{array}$ \\
\hline $\begin{array}{c}\text { Institutional, staff-based } \\
\text { teaching/learning }\end{array}$ & $\begin{array}{c}\text { Fognitive, affective and skills } \\
\text { related objectives }\end{array}$ \\
\hline Low level cognitive learning & Higher level cognitive learning \\
\hline
\end{tabular}

S. Sterling points out that such comparisons are necessary as they reflect all changes of the educational system, and they can be summarized in a paradigm, basic tasks, educational policy and practice $[14,15]$.

Transformative learning stimulates nurses to learn to think independently in order to dispose of the knowledge that has at times been acquired as a result of life experience without ever thinking or asking questions. For nurses to really assume and develop their personal, professional and social roles, the ability of reasoning greatly helps their personality, community/ society and the world, in general, become better. It gives nurses an opportunity to better understand the life of other people. Transformative learning in nursing education has to be understood as a change of learning culture; it has to be evaluated critically and there is no contradiction between the reality and experience where active cooperation with others takes place, applying reflection in order to understand an activity. Reflective thinking is a basis that supports and facilitates the transformation of such a learning perspective.

In the course of time and in the process of development of the dialogue, literature and further inquiry, these wide and still fundamental changes of understanding have been characterized as new perspectives of meaning, new points of reference, new habits of mind and new worldviews $[6,7,8,16,17]$.

\subsection{Transformative Learning and Reflection}

Transformative learning and reflection do not refer only to the education process. It is a manifestation of committed professional performance of a medical nurse in health care environment. Critical thinking and reflection shape the interaction among different specific components of the professional competences of a nurse in the health care process, for example, rationalism - in the health care process, medical nurses rely on facts, not emotions; they rely on objective evidence, taking into consideration all aspects of this evidence, and, by reflecting on this evidence, nurses seek the most favourable justification and solution of a health issue of a patient rather than trying to prove their beliefs and truth. Nurses' reflection on their theoretical activities is a way that explains contemplation, doubt and reflection, full of contradictions, on basic theoretical issues, the bigger questions of human existence, as well as analysis and reflection on their own activities and regularities, their psychological condition, feelings and experiences.

Types and levels of reflection formulated by $\mathrm{J}$. Mezirow in nursing education help teachers and students create a learning process that helps to understand and seek how to acquire wisdom or sagacity.

Reflection on meaning is an examination of the content or description of a problem.

Reflection on process includes an examination of problem- solving strategies.

Reflection on premises leads to the meaning perspective of transformation.

\section{Levels of reflection:}

reflection - understanding that is characterised by a specific perception, meaning, behaviour or habit;

emotional reflection - understanding of how one feels regarding the perceived, his thoughts or actions;

evaluative reflection - evaluation of effectiveness of the perception, thought or habit;

judgmental reflection - evaluation of the perception, thought, behaviour or habit;

conceptual reflection - self-reflection that can raise doubts about the fact if good, bad or appropriate concepts were used in understanding and the evaluation process;

psychic reflection - acknowledges that humans tend to judge and base their judgement on a limited amount of information;

theoretical reflection - understanding that the ability to perceive and evaluate or the habit of conceptual inadequacy lies in cultural or psychological assumptions that are taken for granted, and that explains why a personal experience is more acceptable than another perspective that uses more functional criteria of seeing, thinking or behaviour [6,7]. 


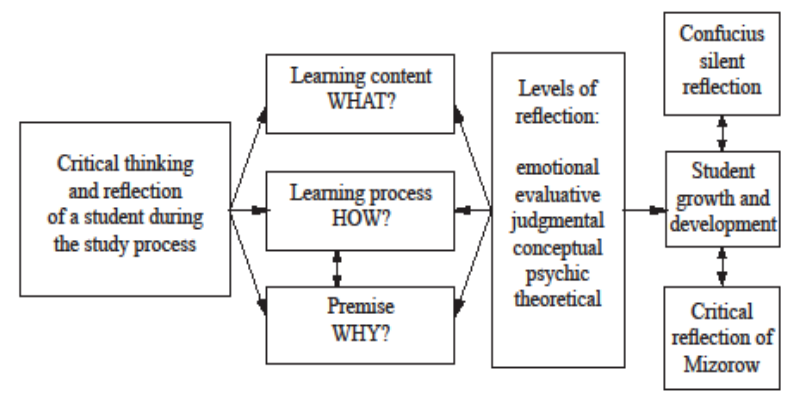

Figure 1. A model of transformative learning and reflection for nurses (Developed on J. Mezirow's theory of critical reflection)

Transformative learning, critical thinking and contemplation that has developed from Confucius' silent reflection and J.Mezirow's theory of critical reflection allow the developers of nursing education programmes to realize how adult education from a seemingly diverse humanistic tradition is heading towards one common goal - education for sustainable development, which is directly linked to the pillars of education for sustainable development of the 21st century or basic learning types. The type of learning supported by Confucius was focused on empirical understanding. However, contemporary learning types are based on the art of argument or a dialogue $[6,7]$.

Transformative learning and J. Mezirow's theory of critical reflection make a useful starting point for developing and building the ecological competence model for nurses. A comparative analysis and reflection on the Eastern and Western theories and philosophy lines lead us to a learning model - transformative learning with the help of critical reflection.

\section{Methodology and Results}

Table 2. Comparison of transmissive and transformative education

\begin{tabular}{|c|c|}
\hline Transmissive education & Transformative education \\
\hline 1 & 2 \\
\hline Instructive learning & Learning by means of discovery \\
\hline Teacher-based teaching/learning & Reciprocal learning \\
\hline Subject-object approach & Subject-subject approach \\
\hline The same information for everyone & Additional information that conforms with the preliminary knowledge \\
\hline Control & Student self-evaluation, self-government \\
\hline Individual learning & Cooperative learning \\
\hline Focus on contents and accumulation of knowledge & Focus on self-regulatory learning and real gain \\
\hline Emphasis only on the cognitive (inquiring) targets & Cognitive (inquiring), as well as emotional, knowledge-oriented targets \\
\hline One-way communication & Discussion, development of the diversity of viewpoints \\
\hline Theory-based learning & Practice-oriented learning that combines theory with practice \\
\hline $\begin{array}{l}\text { Emphasis on accumulation of knowledge and } \\
\text { recognition of contents }\end{array}$ & Emphasis on self-regulatory learning and realization of the real gains \\
\hline Learning objective - only cognition & Learning objective - comprehension of the acquired knowledge and its emotional evaluation \\
\hline
\end{tabular}

The outcomes of the present research characterize the of indicator pairs emerged: 1) the left indicator is first level professional higher education in nursing, which does not include a study course of The Ecological Approach in Education and Health Care.

A survey was carried out with two groups of respondents (twenty one second year students and fifteen first year students) from Nursing study program of a medical college.

Respondents were asked to evaluate the existing and desired study indicators (Table 2) that were developed following Sterling's research [14,15].

Each student individually assessed the 12 pairs of indicators that are given in the tables. Three possible types dominating; 2) the right indicator is dominating; 3) there is no significant dominance of one or the other indicator (in the pair of indicators students have marked both indicators). The significance of differences of each indicator pair was determined using chi-square test $\left(\chi^{2}\right)$. An interactive online calculation tool was used [18]. The observed frequencies of assessments were compared against the expected frequencies (the equal frequencies of both indicators). The observed values of $\chi^{2}$ were compared against the critical values $\chi^{2}$ according to the level of significance: $p \leq \alpha=.01$. The acquired data are summarized in Table 3.

Table 3. The actual and desired education as assessed by students of the Nursing program

\begin{tabular}{|c|c|c|c|c|}
\hline \multirow{2}{*}{ Types of education } & \multicolumn{2}{|l|}{ Actual } & \multicolumn{2}{|l|}{ Desirable } \\
\hline & Number of responses & $\%$ & Number of responses & $\%$ \\
\hline Only transmissive (just one indicator is marked in the 1st column of Table 2) & 255 & 59 & 77 & 23 \\
\hline Transmissive and transformative (In the pair of indicators, both indicators are marked) & 35 & 8 & 40 & 12 \\
\hline Only transformative (just one indicator is marked in the 2nd column of Table 2) & 142 & 33 & 222 & 65 \\
\hline Total & 432 & 100 & 339 & 100 \\
\hline
\end{tabular}

The total number of possible responses evaluating the 12 pairs of indicators: 12 x $36=432$. In the current characterization of nursing education the indicators that correspond to transmissive education are dominant: 59\% of all responses; $33 \%$ of indicators correspond to transformative education. The dominance of either transformative or transmissive education was not established in only $8 \%$ of the responses - both indicators of the pair were marked. The actual situation does not conform to the desires and expectations of students: in $65 \%$ of the responses indicators that correspond to transformative education are dominant. Parts of respondents have not marked the indicators that correspond to the desired education therefore the total number of responses is different. Differences in the number of responses that correspond to transmissive and transformative education both in the assessment of the actual and desired education are statistically significant: $p$ $<.001$.

The acquired data highlights the necessity for change in the organization of the educational process and the need to ensure a paradigm shift - transition from a mechanical 
paradigm to an ecological paradigm and from transmissive to transformative teaching and learning.

By integrating the course of The Ecological Approach in Education and Health Care in the study programme of Nursing, experimental transformative research, applied as a diagnostic tool, was carried out to determine knowledge transformation during the course, for example, the understanding and application of the concept ecology , and its significance in education and health care.

A transformative mixed research paradigm provides a philosophical framework that is aimed at the formation of the ecological consciousness and development process of the ecological competence in nursing education and health care revealing the diversity of its environmental dimensions.

Transformative mixed and cyclic research methods were applied to illustrate the methodological implications of the transformative paradigm with an aim to find a way how to promote and integrate the ecological approach in nursing education and health care practices, as well as encourage the transformation of I-Ego of medical nurses to I-Eco in social, education and health care environment.

\section{Discussion}

During discussions with students, it was established that evaluation of the desired education was affected by the insufficient understanding of the importance of transformative education from both students' and teachers' point of view. It was confirmed by the research on the importance of the pillars of education in different educational programs [2]. During the research it was established that the pillar 'learning to transform oneself and society' received a relatively lower evaluation in nursing and also other educational programs. The dominating view was that transforming oneself is mainly possible through informal education rather than in the framework of formal or non-formal education.

After a survey of nurses doing a professional development program, it was established that the ecology of education is mainly associated with the environmental protection and not with the ecological approach in education. General observations have lead to a conclusion that such an understanding of the ecology of education is dominant also among the faculty and teaching staff of nursing study programs.

Comparing the results of our research with similar research in educational programs of other medical colleges in Latvia, it can be concluded that in the examined nursing study programs the progress towards transformative education is less pronounced. Separate case studies performed at two medical colleges of Latvia showed that $70 \%$ of indicators, analogous to the ones used in the research, were evaluated as appropriate to transformative education.

\section{Conclusion}

Education for sustainable development is a global tendency of the 21st century. Transformative education is in line with this global trend and as such should be implemented in nursing study programs. A comparative assessment of indicators of transmissive and transformative education performed by students of nursing programs clearly demonstrated that transmissive education patterns are dominating contemporary studies. However, it also showed that students desire transformative education. In the assessed nursing study program, the progress towards transformative education is less pronounced than in the study programs of other colleges. Therefore the transition towards and actualization of transformative education has become an essential objective for further improvement of study programs.

\section{References}

[1] UN Economic Commission for Europe Committee on Environmental Policy. Some terms used in the strategy for education for sustainable development, 2004. Available at http://www.unece.org/env/cep/11thsession.html

[2] Briede B., Pēks L. Ecological Approach in Education [electronic resource]. Jelgava, Latvia University of Agriculture, Institute of Education and Home Economics, 2011, 160. Monographic research series Ecology of Education. CD-ROM. ISBN 9789984480473. (In Latvian)

[3] O’Sullivan E. Transformative Learning - Educational Vision for the 21st century. London: OISE/UT/Zed Books, 1999.

[4] Stacey R. Strategic Management and Organisational Dynamics. London: Pitman, 1996.

[5] Mezirow J. Education for perspective transformation; Women's re-entry programs in community colleges. New York: Teacher's College, Columbia University, 1978.

[6] Mezirow J. Transformative learning: Theory to practice. In P. Cranton (Ed.). Transformative learning in action. New Directions in Adult and Continuing Education, no. 74. San Francisco: JosseyBass, 1997, 5-12.

[7] Mezirow J. (Ed.) Learning as transformation: Critical perspectives on a theory in progress. San Francisco: Jossey-Bass, 2000, 125-148.

[8] Baumgartner L., Merriam S. Adult learning and development: Multicultural stories. San Francisco: Jossey-Bass, 1999.

[9] Boyd, R. D., Fales A. Reflective learning: key to learning from experience. Journal of Humanistic Psychology, 23(2), 1983, 99117.

[10] Cranton, P. Understanding and promoting transformative learning. San Francisco: Jossey-Bass, 1994.

[11] Dirkx J. Nurturing the soul in adult learning. In P. Cranton (Ed.). Transformative learning in action. New Directions in Adult and Continuing Education, No. 74. San Francisco: Jossey-Bass, 1997, 79-88.

[12] Elias J. L., Merriam S. B. Philosophical foundations of adult education. Malabar, Florida: Krieger Publishing Company, 1995.

[13] King K. P. Transformative learning. In S. Farmer \& S. Stein (Eds.) Connotative learning. Washington DC: IACET, 2004, 195-206.

[14] Sterling S. Sustainable Education, Green Books for the Schumacher Society, Bristol, 2004.

[15] Sterling S. Whole Systems Thinking as a Basis for Paradigm Change in Education: Explorations in the Context of Sustainability. (PhD thesis), Centre for Research in Education and the Environment, University of Bath, 2005. Available at http://www.bath.ac.uk/cree/sterling/sterlingtitle.pdf

[16] King K. P. Keeping pace with technology: Educational technology that transforms. Vol. 1: The challenge and promise for K-12 educators. Cresskill, NJ: Hampton Press, 2002.

[17] King K. P. Keeping pace with technology: Educational technology that transforms. Vol. 2: The challenge and promise for higher education faculty. Cresskill, NJ: Hampton Press, 2003.

[18] Preacher K. J. Calculation for the chi-square test: An interactive calculation tool for chi-square tests of goodness of fit and independence, 2001. [Computer software]. Available at http://www.quantpsy.org/chisq/chisq.htm 